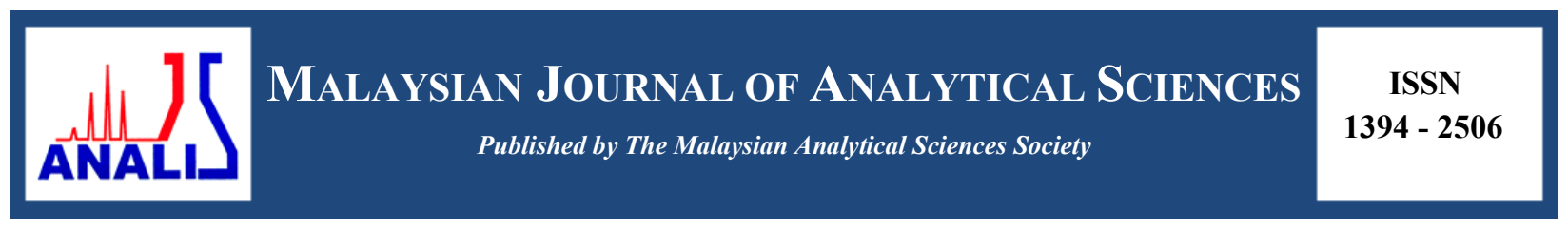

\title{
THE EFFECT OF POLYMER CONCENTRATION AND SURFACTANT TYPES ON NANOFILTRATION-SURFACTANT MEMBRANE FOR TEXTILE WASTEWATER
}

\section{(Kesan Kepekatan Polimer dan Jenis Surfaktan pada Membran Surfaktan Penurasan-Nano untuk Air Sisa Tekstil)}

\author{
Sarah Husnaini Zainal, Abdul Rahman Hassan*, Mohd Hafez Mohd Isa \\ Industrial Membrane Technology Laboratory, Department of Industrial Chemical Technology, \\ Faculty of Science and Technology, \\ Universiti Sains Islam Malaysia, 71800 Nilai, Negeri Sembilan, Malaysia \\ *Corresponding author: abdrahman@usim.edu.my
}

Received: 24 February 2015; Accepted: 27 October 2015

\begin{abstract}
In this study, an asymmetric nanofiltration-surfactant (NFS) membrane was prepared via simple dry/wet phase inversion technique. A newly dope formulation consisting of different surfactants (SDS, CTAB) and polymer concentration (17 wt $\%$ - 21 $\mathrm{wt} \%$ ) were developed. The effect of these parameters on dyes performance in terms of dyes flux, rejection and morphological structure were examined. Experimental data showed that, at different ranges of polymer concentration, NFS membranes shows low permeation flux of dyes ranging from $9.256 \mathrm{~L} / \mathrm{m}^{2} \mathrm{~h}$ to $14.315 \mathrm{~L} / \mathrm{m}^{2} \mathrm{~h}$ at 4 bar operating pressure. Significantly, the addition of SDS and CTAB surfactants were found to promote the increasing of dyes flux and rejection up to $79.698 \mathrm{~L} / \mathrm{m}^{2} \mathrm{~h}$ and $99.5 \%$ respectively. Addition of surfactant shows the membrane surface morphology with upper layer and support layer consists of finger-like structure, finger-like channel, macrovoids and spongy structure.
\end{abstract}

Keywords: nanofiltration, surfactant, flux, rejection, morphological structure

\section{Abstrak}

Dalam kajian ini, membran surfaktan penurasan-nano telah disediakan melalui teknik fasa berbalik kering/basah mudah. Satu formulasi baru polimer yang terdiri daripada surfaktan yang berbeza (SDS,CTAB) dan kepekatan polimer $(17 \mathrm{wt} \%-21 \mathrm{wt} \%)$ telah disediakan. Kesan parameter ini terhadap prestasi pewarna dari segi fluks warna, penolakan dan struktur morfologi telah diperiksa. Data ujikaji menunjukkan bahawa, pada jarak yang berbeza kepekatan polimer, keputusan fluks membran NFS menyerap rendah pewarna antara $9.256 \mathrm{~L} / \mathrm{m}^{2} \mathrm{~h}$ kepada $14.315 \mathrm{~L} / \mathrm{m}^{2} \mathrm{~h}$ pada 4 bar tekanan operasi. Lebih penting lagi, penambahan SDS dan CTAB sebagai surfaktan didapati menggalakkan peningkatan fluks pewarna dan penolakan sehingga masing - masing adalah $79.698 \mathrm{~L} / \mathrm{m}^{2} \mathrm{~h}$ dan $99.5 \%$. Penambahan surfaktan menunjukkan morfologi permukaan membran dengan lapisan atas dan lapisan sokongan yang terdiri daripada struktur jejari, saluran jejari, makrovoid dan struktur lembut.

Kata kunci: penurasan-nano, surfaktan, fluks, penolakan, struktur morfologi

\section{Introduction}

Nanofiltration (NF) membrane one of the promising technologies which has been largely developed and commercialized for the separation of neutral and charged solutes in the aqueous solutions. NF membranes has two remarkable features which are has molecular weight cut-off (MWCO) between reverse osmosis (RO) membranes 
and ultrafiltration (UF) membranes ranges from 200 to $2000 \mathrm{Da}$. The other advantage of NF where it can separate electrolytes due to the materials containing charged groups [1]. According to these features, the separation mechanisms involve both steric and electrostatic partitioning effects between the membrane and external solutions. The combination between steric and electrostatic allows NF membranes more effective for the separations of mixtures of organic molecules and salts. An NF membranes main feature is that most of them are charged either positively or negatively depends on their materials [2].

In this study, asymmetric nanofiltration membranes were prepared via dry/wet phase inversion techniques. This technique has been introduced by Loeb and Sourirajan which is the most extensively used technique for the preparation of asymmetric membranes. In this technique, the solution was cast on a substrate/glass was immersed and precipitated in a water bath. In dry/wet phase inversion technique, solvent in the casting solution was exchanged with non-solvent and phase separation will occurs in the film. This will be resulted to the morphology of asymmetric membranes showing a dense top layer and porous sub-layer membranes [3]. Addition of surfactant as additive in the polymer solution was the new materials used in formulating new NF membranes. Surfactant has been used in soaps, laundry detergents, dishwashing liquids and shampoos are organic chemicals that reduce surface tension in water and other liquids. Surfactant also can be considered as amphiphilic due to the two parts which are hydrophilic and hydrophobic parts [4].

Addition of surfactant has been studied by several researchers which gives high membrane performance. According to Tsai et al. [5], addition of surfactants in the casting solution can influence the formation process of macrovoids. Moreover, the size of macrovoids decreases when the surfactant content increase [5]. Furthermore, Amirilargani et al. [6] discovered that addition of non-ionic surfactant in the casting solutions shows that the macrovoids and fingerlike pores in the sub-layer can be induced or suppressed depending on their miscibility. It was also found that the addition of small amount of surfactant will increase the water content, porosity and thickness of the prepared membranes [6].

\section{Chemicals and raw materials}

\section{Materials and Methods}

Polyethersulfone (PES) was purchased from SOLVAY Advanced Polymers Company (RADEL A-300). 1-Methyl2-Pyrrolidone (NMP) with analytical purity of $99.5 \%$ (Merck), ethanol and n-hexane (Merck) was used as pretreatment solutions in membrane fabrication. Polyethylene glycol (PEG) with average molecular weight of $600 \mathrm{~g} / \mathrm{mol}$ (Merck) used as additive. Cetyltrimethylammonium bromide (CTAB) with molecular weight of $364.5 \mathrm{~g} / \mathrm{mol}$ from EMD Chemicals and Sodium dodecyl sulfate (SDS) with molecular weight of $288.37 \mathrm{~g} / \mathrm{mol}$ (Merck) were used as surfactant addition in the polymer solution. Methyl violet from Blulux Laboratory Reagents and Methyl blue (Merck) were used as synthetic dyes.

\section{Membrane preparation and fabrication}

NMP was used to dissolve polymer in polymer solution method. NMP was heated at about $50{ }^{\circ} \mathrm{C}$ and PES was dissolved. PEG 600 was added when polymer has been dissolved. The solution was stirred for 8 hours to get homogenous solution. Then, surfactant was added 3 hours before the polymer solution was completed. After formation of polymer solution has been completed, casting process will take place in fabricated thin film of membrane. The casting process was conducted at room temperature $\left(30 \pm 2{ }^{\circ} \mathrm{C}\right)$. Small amount of polymer solution was poured onto glass plate as support layer with casting knife setting at $150 \mu \mathrm{m}$. After the membrane has been casted, the glass plate support together with membrane was immersed into the coagulation bath. When the coagulation process was completed, the membrane was immersed in water bath for 24 hours before it was immersed in ethanol for another 24 hours. Finally, the resulted membrane was soaked in n-hexane for 2-3 hours before dried at room temperature at least for 24 hours. The prepared polymer solution concentration was varied from $17 \mathrm{wt} \%$ to 21 wt $\%$.

\section{Membrane performance evaluation}

The permeation test was conducted by using a simple dead-end permeation cell. Prior to the testing, each membrane was subjected for the passages of the first $10 \mathrm{ml}$ permeate was collected. The pure water permeation was calculated using equation 1 below: 
Volume of Permeate Solution Collected

$$
\text { Pure Water Permeation }=\frac{\text { Effective Membrane Area } \mathrm{x} \text { Time }}{\text { Pim }}
$$

To study the effect of dyes rejection, operating pressure at 4 bar was used to obtain respective flux. Permeation flux test of dyes was carried out using three types of dyes (methyl violet, methyl blue, acid orange) at 3 different concentrations (10ppm, 15ppm, 20ppm). The volume flux and rejection was calculated using formula equation 2 below:

$$
\text { Percentage of Rejection }=1-\frac{\text { Concentration Permeate }}{\text { Concentration Feed }} \quad \times 100 \%
$$

\section{Dyes permeation flux and rejection}

\section{Results and Discussion}

Three different dyes were used in this study (Methyl Violet, Methyl Blue, and Acid Orange) in order to determine the membrane performance in terms of permeation flux and dye rejection. Three different concentrations (10 ppm, $15 \mathrm{ppm}, 20 \mathrm{ppm}$ ) of Methyl Violet has been used in order to find the significance difference of each prepared membrane and each concentration will give difference permeation flux and rejection results. Figure 1(a) shows the permeation flux of Methyl Violet at three different dyes concentration of membrane with SDS surfactant. Since 10 $\mathrm{ppm}$ is the lowest dye concentration, it shows highest flux among other concentration of about, $38.836 \mathrm{~L} / \mathrm{m}^{2} \mathrm{~h}$. However, the permeate flux keep increasing as polymer concentration increase up to $79.697 \mathrm{~L} / \mathrm{m}^{2} \mathrm{~h}$. The rejection of $10 \mathrm{ppm}$ concentration of Methyl Violet shows that as polymer concentration increase, the rejection will decrease from $79 \%$ to $66.2 \%$. Unlike the lower dye concentration, at $13.776 \mathrm{~L} / \mathrm{m}^{2} \mathrm{~h}$, the membrane can reject dye only $33.3 \%$ at $15 \mathrm{ppm}$ dye concentration. Since polymer concentration also plays an important role in this study, the color rejection of Methyl Violet increase sharply up to $79 \%$ at higher polymer concentration (21 wt $\%$ ). As dye concentration increase to $20 \mathrm{ppm}$, the permeate flux decreased to $11.0843 \mathrm{~L} / \mathrm{m}^{2} \mathrm{~h}$. However, for $20 \mathrm{ppm}$ of dye concentration, the three different polymer concentrations resulted to the same rejection. Research revealed that addition of surfactants in casting solution will influence the formation of macrovoids [7].



Figure 1. (a) Permeate flux and (b) \% rejection of Methyl Violet 
Experimental data shows that addition of SDS in polymer solution is not good for dyes rejection. Figure 2(a) and 2(b) shows permeation flux and percentage rejection of Methyl Blue when CTAB was used as surfactant. The highest permeate flux were obtained from the lowest polymer concentration at the lowest dye concentration. At $44.565 \mathrm{~L} / \mathrm{m}^{2} \mathrm{~h}, \mathrm{M} 1$ can remove dye of about $99.2 \%$ at $10 \mathrm{ppm}$ dye concentration. The results also show that, as polymer concentration increased, the permeate flux decreased up to $13.682 \mathrm{~L} / \mathrm{m}^{2} \mathrm{~h}$ and increase the rejection to 99.5\% for M3. According to Rahimpour et al. [7], addition of CTAB surfactant in polymer solution will gives membrane with large pores that formed in the sub-layer of the membrane. Moreover, addition of CTAB was known to be capable to increase the porosity of membrane support layer and result in high rejection of Methyl Blue [8]. At $15 \mathrm{ppm}$ of dye concentration, the permeate flux shows the same results where the flux decrease when polymer concentration increase from $27.758 \mathrm{~L} / \mathrm{m}^{2} \mathrm{~h}$ to $9.272 \mathrm{~L} / \mathrm{m}^{2} \mathrm{~h}$. Moreover, the rejection of Methyl Blue at $15 \mathrm{ppm}$ dye concentration increasing up to $99.1 \%$ for M3. An amount of $21 \mathrm{wt} \%$ PES shows $8.972 \mathrm{~L} / \mathrm{m}^{2} \mathrm{~h}$ of permeation flux and can reject dye up to $99.9 \%$ at $20 \mathrm{ppm}$ of dye concentration.

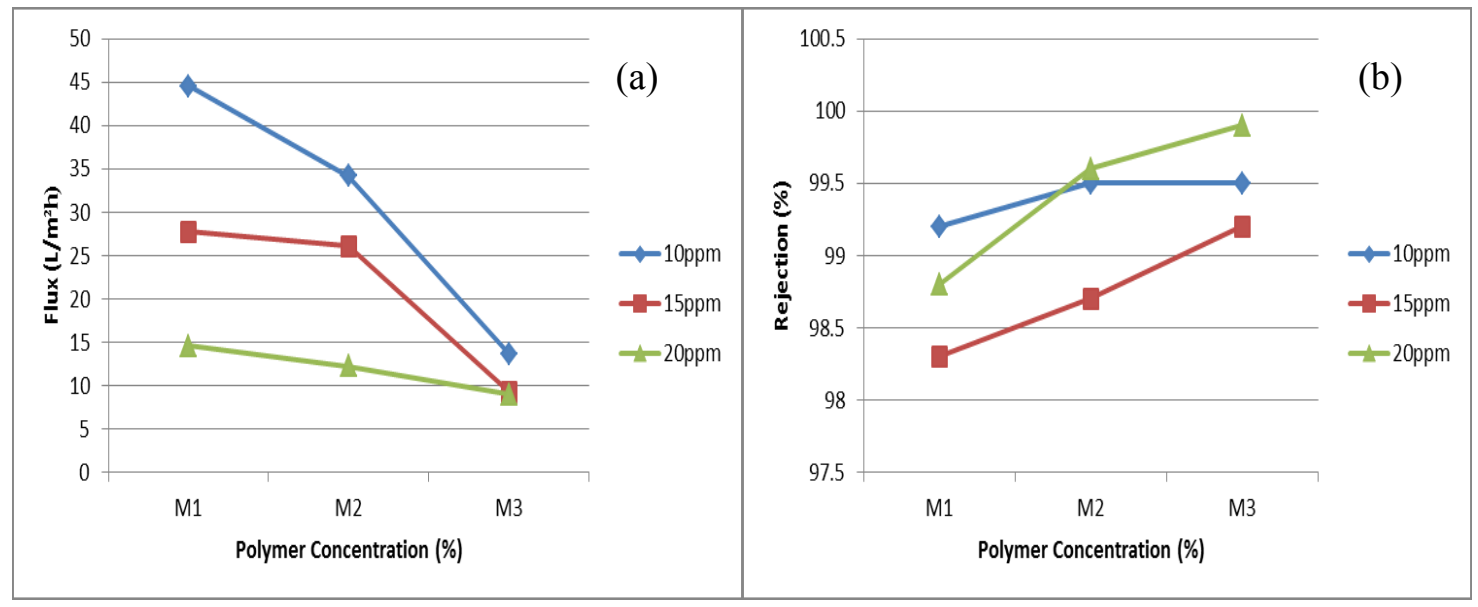

Figure 2. (a) Permeate flux and (b) \% rejection of Methyl Blue

In order to complete the study, acid orange also was used to test the membrane performance (Figure 3). The same trend shown between Methyl Blue and Acid Orange in which the permeation flux decreased as polymer concentration increased with increasing of dye concentration. On the other hand, the rejection of acid orange was increased as polymer concentration increase also with increasing of dye concentration. At $51.044 \mathrm{~L} / \mathrm{m}^{2} \mathrm{~h}$, M1 gives dye rejection of $90.7 \%$ for $10 \mathrm{ppm}$ dye concentration. Research proved that concentration of feed solutions is one of parameters that affects the membrane performance [9]. Permeate flux of Acid Orange decreased and rejection also increased when dye concentration increased. For $15 \mathrm{ppm}$ dye concentration, M1 gives $46.898 \mathrm{~L} / \mathrm{m}^{2} \mathrm{~h}$ of permeation flux and decreased to $15.871 \mathrm{~L} / \mathrm{m}^{2} \mathrm{~h}$ indicate as the polymer concentration increased to $\mathrm{M} 3(21 \mathrm{wt} \%)$. Permeation flux of Acid Orange decreased and has increased the rejection up to $94.9 \%$. Furthermore, morphological structures of prepared membrane also was the most important parameters that gives high or low rejection towards dye solutions. At $12.175 \mathrm{~L} / \mathrm{m}^{2} \mathrm{~h}, 20 \mathrm{ppm}$ of Acid Orange dye concentration gives $94.1 \%$ of dye rejection. This can be conclude that, for Acid Orange with lower molecular weight will decreased the permeation flux and increased the rejection as polymer concentration increased as well as dye concentration increased.

\section{Morphological study}

Figure 4a shows the image of nanofiltration membrane without surfactants. It can be seen that the resultant asymmetric membranes consist of dense top-layer and finger-like substructure. The cross-sectional image revealed that increasing of polymer concentration will increase the number of pores on the top-layer of the membranes. The long finger-like substructure is the key towards the performance of membranes. The support layer is thick that make the solutions harder to pass through the membranes. Addition of small amount SDS surfactant was shown by Figure 
$4 \mathrm{~b}$ where different morphological structure produced. SDS makes the membrane structure more porous in terms of formation of larger macrovoids. Moreover, the support layer of membranes also containing microvoids that leads to the lower mechanical strength of the membrane. In order to study the effect of different type of surfactant on membrane performance, Figure 4c shows SEM image of membrane with CTAB. Addition of CTAB on polymer solution shows the formation of long finger-like structure across the substructure of the membrane. From the previous study, the SEM images shows the formation of large pores in the sub-layer of membrane with addition of $\mathrm{CTAB}$. This phenomenon is due to the miscibility of the surfactant and coagulant. Other than that, addition of $\mathrm{CTAB}$ revealed that it will induces and extends the formation of macrovoids as well as finger-like pores in the support layer of membranes [10]. From the experimental data, membrane with CTAB shows lower flux and high rejection of dyes.



Figure 3. (a) Permeate flux and (b) \% rejection of Acid Orange
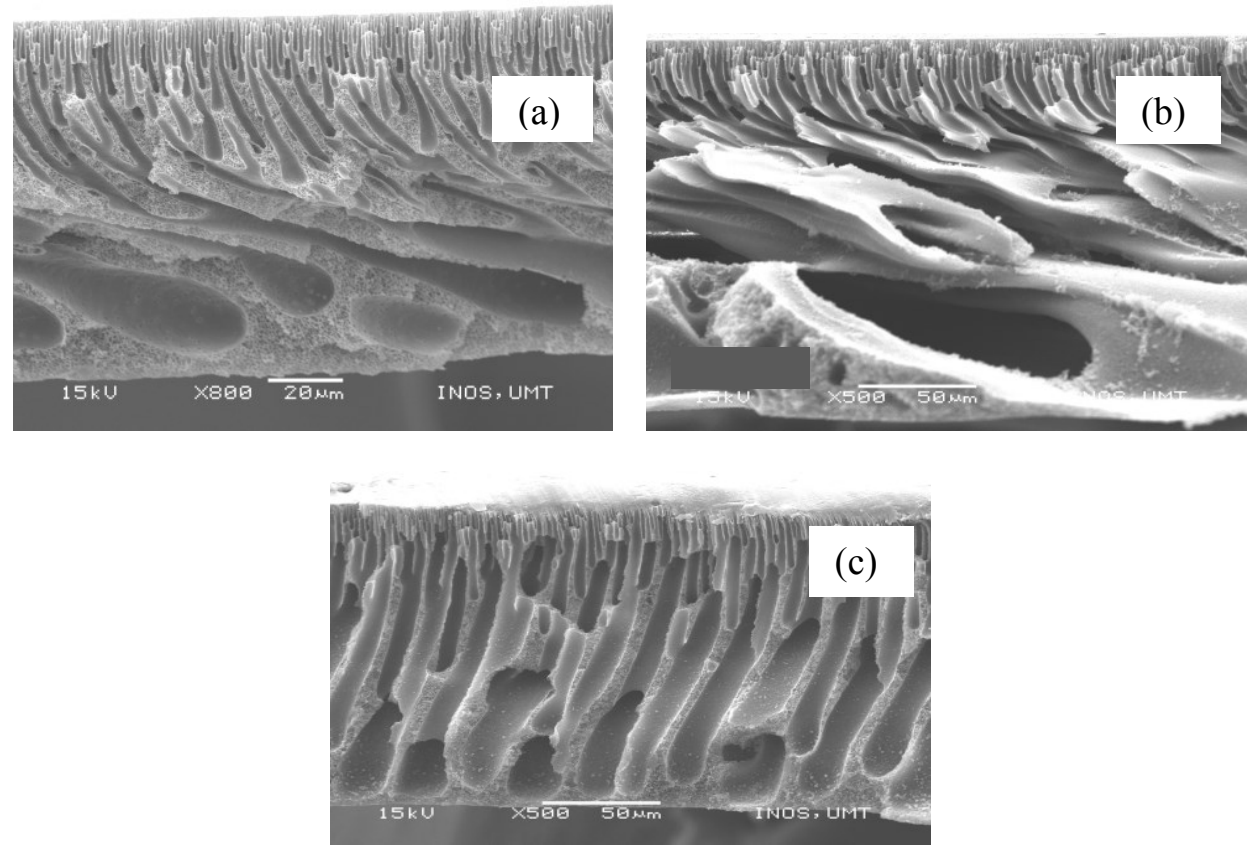

Figure 4. SEM images on (a) NF membrane (b) NF membrane with SDS and (c) NF membrane with CTAB at $800 x$ of magnification 


\section{Conclusion}

Experimental data shows the highest rejection of dyes was obtained by membrane contains CTAB as surfactant. Increased the rejection $\mathrm{p}$ to $99.9 \%$ it could be comparable to commercial membrane in the industry. With fine morphological structure consists of dense top-layer, long finger-like structure and stable support layer, membrane with $\mathrm{CTAB}$ is the best membranes to be used in textile industries in Malaysia. Besides, CTAB is readily available and very economical to use in making membrane.

\section{Acknowledgement}

The authors would like to thank the Research Management Centre (RMC), Universiti Sains Islam Malaysia (USIM) and KPT for financing the project under the Exploratory Research Grant Scheme (USIM/ERGS-FST-33-50113).

\section{References}

1. Wang, X. L., Shang, W. J., Wang, D. X., Lu, L. and Tu, C. H. (2009). Characterization and applications of nanofiltration membranes: State of the art, Desalination, 236: 316 - 326.

2. Ismail, A. F. and Hassan, A. R. (2004). The deduction of fine structural details of asymmetric nanofiltration membranes using theoretical models. Journal of Membranes Science, 231: 25 - 36.

3. Ismail, A. F. and Hassan, A. R. (2006). Formation and characterization of asymmetric nanofiltration membrane: Effect of shear rate and polymer concentration. Journal of Membrane Science, 270: 57 - 72.

4. Kowalska, I., Korbutowicz, M. K., Nowak, K. M. and Winnicki, T. (2004). Separation of anionic surfactants on ultrafiltration membranes. Desalination, 162: $33-40$.

5. Tsai, H.A., Li, L. D., Lee, K. R., Wang, Y. C., Li, C. L., Huang, J. and Lai, J. Y. (2000). Effect of surfactant addition on the morphology and pervaporation performance of asymmetric polysulfone membranes. Journal of Membrane Science, 176: 97 - 103.

6. Amirilargani, M., Saljoughi, E. and Mohammadi, T. (2009). Effects of Tween-80 concentration as a surfactant additive on morphology and permeability of flat sheet polyethersulfone (PES) membrane. Desalination, 249: $837-842$.

7. Rahimpour, A., Madaeni, S. S. and Mansourpanah, Y. (2007). The effect of anionic, non-ionic and cationic surfactants on morphology and performance of polyethersulfone ultrafiltration membranes for milk concentration. Journal of Membrane Science, 296: 110 - 121.

8. Akbari, A., Remigy, J. C. and Aptel, P. (2002). Treatment of textile effluent using a polyamide-based nanofiltration membrane. Chemical Engineering and Processing, 41: $601-609$.

9. Huang, J., Liu, L., Zeng, G., Li, X., Peng, L., Li, F., Jiang, Y., Zhao, Y. and Huang, X. (2014). Influence of feed concentration and transmembrane pressure on membrane fouling and effect of hydraulic on the performance of ultrafiltration. Desalination, 335: $1-8$.

10. Saedi, S., Madaeni, S. S., Shamsabadi, A. A. and Mottaghi, F. (2012). The effect of surfactants on the structure and performance of pes membrane for separation of carbon dioxide from methane. Separation and Purification Technology, 99: $104-119$. 